\title{
IBM PEMBERDAYAAN KELOMPOK TERNAK KAMBING ETAWA MELALUI PELATIHAN DAN PENDAMPINGAN DALAM PRODUKSI SILASE SEBAGAI PAKAN TERNAK ALTERNATIF DI DESA WONGSOREJO
}

\author{
Mustofa Hilmi" ${ }^{\# 1}$ Endi Sailul Haq" ${ }^{\# 2}$ Farisqi Panduardi"\#3 \\ ${ }^{1}$ Program Studi Teknologi Pengolahan Hasil Ternak ,Politeknik Negeri Banyuwangi \\ 2, 3 Program Studi Teknik Informatika ,Politeknik Negeri Banyuwangi \\ 1Mustofahilmi@poliwangi.ac.id, 2esailulhaq@gmail.com, 3akufarisqi@gmail.com
}

\begin{abstract}
ABSTRAK
Peternak wilayah Wongsorejo juga terlahir melalui penelitian sejarah yang panjang, hingga para penerusnya hanya tinggal meluruskan kebiasaan mereka yang mencampur pakan ternaknya secara variasi dari rerumputan hingga daun-daunan. Pemberian pakan yang terus menerus juga tidak baik, karena kambing etawa itu adalah golongan kambing yang memamah biak maka jika diberikan pakan terus menerus di tempat pakan maka kambing etawa cenderung akan memakan terus pakan yang tersedia. Kelompok Ternak Kambing "Joyo Panggung" yang sebagian besar juga merupakan petani berperan dalam menyediakan tempat pelaksanaan kegiatan IbM yang sekaligus sebagai objek utama dari pengabdian ini, permasalahan yang dihadapi oleh kelompok ternak ini adalah Waktu yang diperlukan untuk mencari pakan ternak setiap hari membutuhkan waktu selama 2 jam, Pakan ternak hijauan sangat susah didapatkan, Harga pakan ternak pendukung (ampas tahu dan bekatul), sangat mahal, Ketika panen jagung, batang dan kulit jagung tidak diolah dengan baik, Produktivitas kambing menurun. Solusi yang ditawarkan adalah dengan mengaplikasikan teknologi mesin penghancur jagung dan jerami serta pelatihan dan pendampingan pengolahan pakan ternak alternatif tersebut yang dapat menggantikan pakan ternak hijauan. Kontribusi yang paling mendasar jika teknologi ini diterapkan adalah dapat membantu peternak dalam mendapatkan pakan ternak. Di samping itu, dapat meningkatkan kesejahteraan warga di kelompok ternak kambing "Joyo Panggung" karena silase yang dihasilkan dapat dijual selain dipakai sendiri. Dari sisi pertanian adalah dapat menambah nilai jual hasil panen jagung. Hal ini dikarenakan sebagian besar anggota kelompok ternak "joyo Panggung" juga memiliki lahan pertanian. Rencana luaran pokok dari kegiatan ini adalah sebuah produk yang berupa mesin penghancur jagung dan jerami. Di samping itu dalam kegiatan ini juga ditargetkan luaran yang berupa jasa workshop bagi para pekerja dalam menggunakan mesin tersebut dan juga disampaikan cara - cara yang dapat diaplikasikan dalam setiap proses pembuatan dan pengawetan pakan ternak
\end{abstract}

Keywords - . kelompok ternak “joyo Panggung”, Mesin Pencacah, Silase.

\section{PENDAHULUAN}

Hijauan pakan ternak sampai saat ini masih menjadi andalan peternak wilayah Wongsorejo hingga sampai saat ini, meskipun sudah banyak mengenal tehnologi makanan ternak alternatif. banyak penelitian nutrisi serta pembuatan fermentasi makanan hingga pengenalan konsentrat pada kambing etawa namun tetap saja para peternak lebih mengandalkan hijauan makanan ternak yang dinilai lebih organic dan mudah tata caranya. Waktu pemberian makan dalam keseharian kemudian campuran hijauan atau variasi makanan yang diberikan untuk kambing etawa juga sangat berpengaruh terhadap perkembangan ternak jenis kambing etawa.

Ada beberapa contoh kesalahan perawatan kambing etawa disebabkan oleh factor makanan, yang ada di daerah Wongsorejo ini kegagalannya dipicu oleh pemberian pakan ternak yang monoton hanya dedaunan tertentu saja dalam setiap harinya maka kelengkapan nutrisi tidak pernah didapati dalam sajian pakan ternak tersebut. Tidaklah sulit sebenarnya mempelajari nutrisi yang dibutuhkan karena jika kita manusiakan kambing juga memiliki kebutuhan glukosa yang cukup kemudian protein serta karbohidrat yang terkandung dari dedaunan tersebut. 
Peternak wilayah Wongsorejo juga terlahir melalui penelitian sejarah yang panjang, hingga para penerusnya hanya tinggal meluruskan kebiasaan mereka yang mencampur pakan ternaknya secara variasi dari rerumputan hingga daun daunan. Pemberian pakan yang terus menerus juga tidak baik, karena kambing etawa itu adalah golongan kambing yang memamah biak maka jika diberikan pakan terus menerus di tempat pakan maka kambing etawa cenderung akan memakan terus pakan yang tersedia.

Hal tersbut mengakibatkan saat kambing memamah biak menjadi sedikit sedangkan pengambilan nutrisi yang dibutuhkan oleh ternak kambing etawa adalah saat mereka memamah biak. Jadi jika terus menerus memberikan pakan itu juga berakibat tidak baik dan cenderung menghasilkan kambing buncit namun tidak gemuk .Pemberian konsentrat sebenarnya juga dibolehkan dengan ketentuan bahwa konsentrat tersebut memiliki kandungan nutrisi yang dibutuhkan kambing etawa.

Begitu pula yang terjadi pada sebagian besar kelompok ternak "Joyo Panggung”, berdirinya kelompok ternak ini dilatarbelakangi oleh adanya kesadaran masyarakat petani yang berkeinginan untuuk mengembangkan taraf ekonomi yang dalam hal ini bergerak dalam bidang peternakan.

Wilayah wongsorejo secara geografis terletakk di Kabupaten Banywuangi dan masuk ke dalam kecamatan wongsorejo yang pada umumnya mata pencaharian masyarakatnya di bidang pertanian. Dimana nenek moyang mereka secara turun menurun juga bergerak di dalam budi daya peternakan sapi dan kambing. Dengan adanya potensi alam yang ada, masyarakat berkeinginan mengembangkan ternak tersebut lebih tertata demi pengemabangan ekonomi mereka.

Pakan hijauan sering menjadi masalah bagi peternak kambing dan domba. Selain harus mencari setiap hari yang menyita waktu, ketersediaan hijauan juga tak pasti. Pada musim hujan, memang banyak tersedia. Sebaliknya pada musim kemarau, hijauan susah diperoleh. Bahkan pada waktu-waktu tertentu, misalnya saat musim panen padi, singkong, jagung, kedelai dan sayuran lainnya, banyak limbah hijauan yang terbuang. Padahal, semua bahan tersebut bisa diawetkan dengan cara fermentasi.

Banyak juga calon peternak ataupun calon investor peternakan, khususnya domba dan kambing, yang mengurungkan niatnya untuk budidaya ketika harus berhitung dengan permasalahan pakan hijauan. Mereka ragu apakah mampu menyediakan pakan secara kontinu, apalagi jika jumlah ternaknya banyak.

Bahkan di tingkat peternak kecilpun ketika musim kemarau tiba mereka terpaksa menjual sebagian ternaknya karena khawatir tak mampu memberi pakan akibat terbatasnya hijauan yang tersedia.

Kebutuhan hijauan akan semakin banyak sesuai dengan bertambahnya jumlah populasi ternak yang dimiliki. Kendala utama di dalam penyediaan hijauan pakan untuk ternak terutama produksinya tidak dapat tetap sepanjang tahun. Pada saat musim penghujan, produksi hijauan makanan ternak akan melimpah, sebaliknya pada saat musim kemarau tingkat produksinya akan rendah, atau bahkan dapat berkurang sama sekali.

Ketersediaan hijauan makanan ternak yang tidak tetap sepanjang tahun, maka diperlukan budidaya hijauan pakan, baik dengan usaha perbaikan manajemen tanaman keras atau penggalakan cara pengelolaan penanaman rumput unggul sehingga mutu setiap jenis hijauan yang diwariskan oleh sifat enetic ene dipertahankan atau ditingkatkan. Dengan cara demikian kekurangan akan hijauan pakan dapat diatasi, sehingga nantinya dapat mendukung pengembangan usaha ternak ruminansia yang akan dilakukan.

Dari berbagai masalah yang dihadapi oleh Mitra IbM tersebut maka disimpulkan pendekatan atau solusi yang ditawarkan adalah dalam usaha pembuatan pakan ternak dan meningkatkan pendapatan ekonomi Mitra IbM. Serta meningkatkan kemampuan SDM di Mitra IbM sehingga dapat membuat silase secara mandiri. Oleh sebab itu maka sesuai dengan prioritas kebutuhan maka ditawarkan beberapa solusi yang terhadap permasalah yang dihadapi Mitra IbM yakni : merancang mesin penghalus tanah serta memberikan workshop terkait dengan perancangan, cara kerja, dan perawatan mesin pencacah jagung tersebut.

\section{TARGET DAN LUARAN}

\section{Pembuatan mesin pencacah}

Tanaman mempunyai kecepatan tumbuh yang besar di musim penghujan, jadi ketersediaan hijauan ataupun limbah hasil pertanian pada musim tersebut akan berlimpah (jerami padi,sisa tanaman jagung,kacangkacangan). Fungsi pengawetan akan tercapai bila setelah hijauan ataupun limbah pertanian dipanen segera dilakukan pencacahan baik dengan mesin pencacah rumput 
Hal ini merupakan upaya agar proses respirasi yang terjadi pada sel tanaman segera terputus dan berhenti. Tujuannya adalah agar kandungan air hijauan dapat mencapai titik dimana aktivitas air dalam sel tanaman dapat mencegah perkembangan mikroba. Pengawetan tersebut akan berdampak pada keadaan fisik serta komposisi kimia hijauan tersebut antara lain dengan kehilangan sebagian dari zat makanan (gizi tanaman/nutrien) yang nantinya akan berdampak pada nilai nutrisi hijauan tersebut.

Pada prinsipnya pembuatan silase dengan bahan baku rumput gajah maupun tebon jagung adalah sama. Tetapi untuk hasil yang terbaik terutama dalam hal kandungan nutrisinya lebih direkomendasikan menggunakan tebon jagung. Meskipun harganya mahal, tebon jagung memiliki kandungan gizi yang lebih baik daripada rumput gajah. Untuk diolah menjadi silase tebon dibutuhkan tebon dengan maturity atau umur panen yang agak tua karena kandungan airnya sudah tidak terlalu banyak.

Pengawetan rumput maupun tebon dengan membuatnya menjadi silase salah satu tujuannya adalah sebagai antisipasi kemarau karena seperti yang sering terjadi sepanjang tahun kondisi kemarau bisa berubah-ubah kadang waktunya panjang kadang waktu kemarau pendek. Sebagai antisipasi kemarau yang panjang inilah kita butuh membuat silase saat panen tebon jagung maupun rumput gajah berlimpah. Dengan penyimpanan bentuk segar berupa silase ini, maka kualitas gizinya tidak menurun secara dratis ketika digunakan $2-6$ bulan kemudian bahkan kita bisa menyimpan silase ini sampai selama 1 tahun lebih

\section{Pelatihan dan pendampingan pembuatan pakan ternak}

Pelatihan dan pendampingan ini sebagai alat bantu para peternak kambing pada kelompok ternak joyo panggung untuk mengetahui cara beternak kambing dan domba yang baik, dapat memilih bibit ternak yang berkualitas, mengetahui jenis - jenis kambing dan domba, mengetahui pakan ternak yang tepat dan menghasilkan kambing dan domba yang berkualitas baik

Target dan Tujuan

- Memberikan pengertian dasar tentang kambing dan domba

- Mengetahui jenis - jenis kambing dan domba yang ada di Indonesia

- Mengetahui pakan ternak yang baik untuk kambing dan domba
- Mengetahui manfaat yang diperoleh dari kambing dan domba

- Menghasilkan kulaitas kambing dan domba yang baik dan sehat

\section{METODE PELAKSANAAN}

Berdasarkan hasil survey yang telah dilakukan sebelumnya, didapatkan beberapa permasalahan yang dihadapi oleh mitra seperti yang telah dipaparkan. Dari berbagai permasalahan yang ada, maka tim pengusul berusaha untuk menciptakan suatu ide kreatif dan inovatif dengan tujuan memberikan suatu teknologi tepat guna untuk meningkatkan kapasitas produksi pakan ternak alternatif dan membantu petani dalam meningkatkan hasil panen pertanian mereka. Strategi yang akan dilakukan dalam kegiatan ini yaitu dengan cara meningkatkan sumber daya manusia melalui aplikasi teknologi modern dalam proses pembuatan silase dari batang jagung, jerami, rumput gajah dll. Juga penyuluhan dan pelatihan untuk pengenalan teknologi tepat guna. Berdasarkan masalah yang dihadapi kelompok tani, akan dilakukan beberapa kegiatan sebagai solusi permasalahan dimana pelaksanaannya diuraikan sebagai berikut:

- Perbaikan teknologi produksi berupa pembuatan mesin pencacah (penggiling) jagung dan jerami

Perbaikan teknologi dilakukan dengan membuat mesin pencacah jaghung dan jerami. Mesin ini merupakan paket teknologi tepat guna sebagai solusi sederhana untuk mengatasi rendahnya produktivitas kelompok tani dalam proses pengolahan pakan ternak alternatif. Prinsip kerja alat ini adalah mencacah batang jagung yang dimasukkan ke dalam ruang pengiling menggunakan pisau penggiling yang diputar oleh motor penggerak dan mengeluarkan hasilnya melalui saluran pengeluaran. Pada proses awal pengerjaan, pertama motor listrik dinnyalakan dengan saklar. Motor litrik menggerakan pulley 1 yang di hubungkan dengan pulley 2 menggunakan Vbelt. Pulley 2 menggerakkan poros dan dilanjutkan ke pisau pisau penghalus. Bahan pupuk organik dimasukkan ke dalam hooper in, kemudian digiling melalui pisau penghalus, kotoran kambing yang sudah selesai digiling keluar melalui saringan dan hopper out.

Alat yang akan dibuat ini cukup mudah dioperasikan. Pengguna hanya perlu melakukan 4 (empat) langkah penting operasi, yaitu:

- menghidupkan mesin ketika mulai menjalankan alat, 
- memasukkan bahan yang akan dicacah melalui saluran masuk,

- mematikan mesin ketika selesai menggunakan.

Spesifikasi alat yang akan dibuat telah disesuaikan dengan kebutuhan kelompok tani sasaran. Mesin ini memiliki panjang $100 \mathrm{~cm}$, lebar $80 \mathrm{~cm}$ dan tinggi $75 \mathrm{~cm}$ terbuat dari plat besi $2 \mathrm{~mm}$ dan rangka besi untuk konstruksi body-nya. Motor penggerak

menggunakan mesin diesel bertenaga $1 \mathrm{HP}$, sedangkan pisau pemotong terbuat dari baja dengan sistem knock down (dapat dibongkar pasang).

Untuk mengukur tingkat keberhasilan kegiatan yang telah dilakukan, maka akan dilakukan evaluasi minimal 3 (tiga) kali, yaitu evaluasi proses, evaluasi akhir, dan evaluasi tindak lanjut. Kegiatan evaluasi ini akan melibatkan tutor/pakar dari Politeknik Negeri Banyuwangi. Kriteria dan indikator pencapaian tujuan dan tolak ukur yang digunakan untuk menjustifikasi tingkat keberhasilan dari kegiatan yang akan dilakukan.

- Pelatihan aplikasi mesin pencacah (penggiling) jagung dan jerami

Mesin pencacah (penggiling) jagung dan jerami ini digunakan untuk mempermudah pekerjaan dan membuat langkah efisiensi produksi lebih cepat, serta mudah dalam penggunaan mesin dan proses penghalusan, sehingga kuantitas produksi dapat ditingkatkan. Melalui pelatihan aplikasi mesin ini para petani diharapkan untuk dapat menggunakan mesin ini dengan baik dan benar sesuai dengan standar operasional prosedur mesin.

- Pelatihan dan pendampingan dalam pembuatan silase.

Pelatihan ini akan dilaksanakan di lokasi Mitra IbM dengan melibatkan semua anggota kelompok ternak joyo panggung. Untuk itu akan didatangkan instruktur dari Dinas peternakan di Banyuwangi yang meliki kompetensi dan mampu memberikan pembinaan serta pendampingan dalam meningkatkan SDM kelompok ternak joyo panggung di dalam proses menyiapkan pakan ternak alternatif sebagai pengganti pakan ternak hijauan di Desa Wongsorejo

\section{HASIL DAN PEMBAHASAN}

Hasil Perancangan dan Pembuatan Alat.
Gambar bagian mesin pencacah pakaan ternak

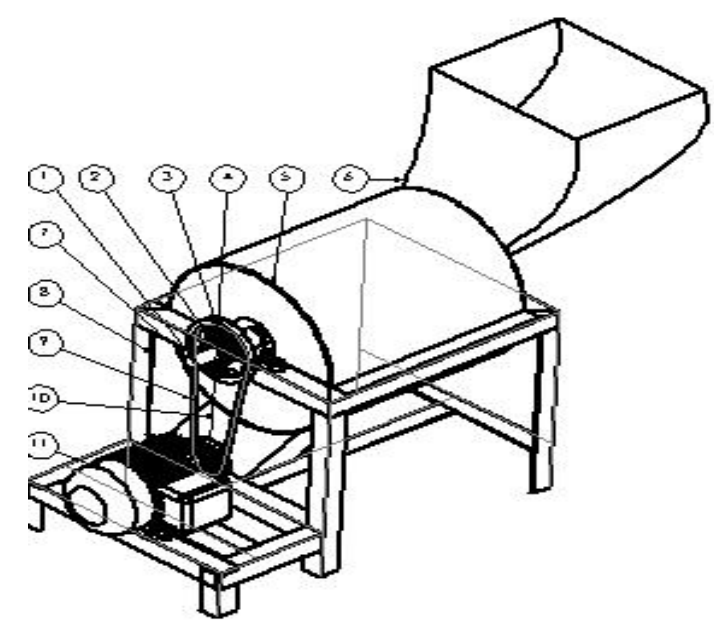

Gambar 1 Desain mesin pencacah

Keterangan :

1. Cruser

2. Rumah Bearing

3. Pulley Penggerak

4. Pulley Yang Digerakan

5. Tabung Atas

6. Hooper

7. Tabung Bawah

8. Kerangka

9. V-Belt

10. Out Put

11. Motor

\section{Cara kerja alat.}

Mesin pencacah pakan ternak ini menggunakan penggerak daya motor listrik,motor listrik meneruskan daya dengan pulley yang terpasang pada poros motor itu sendiri dan pada poros pisau pencacah yang terhubung oleh V-belt.Poros pisau pencacah terpasang pisau yang terbuat dari plat baja dengan jumlah 2 pisau pencacah pada setiap diameter dan disangga oleh bearing pada ujung ujungnya

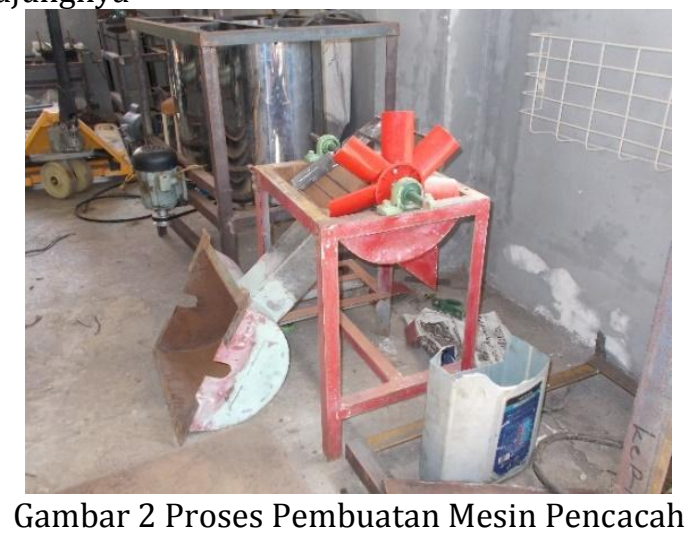


Pakan ternak dimasukkan dalam hooper atau mulut mesin pencacah pakan ternak,kemudian dicacah oleh pisau pencacah yang diputar oleh poros.hasil cacahan keluar melalui lubang autput yang terpasang pada tabung bawah dan didesaign miring agar tidak ada sisa pakan ternak yang tertinggal dalam tabung .

Pengujian Mesin Pencacah Pakan ternak

Pengujian mesin pencacah pakan ternak ini dilakukan di laboratorium pemesinan program studi teknik mesin, Politeknik Banyuwangi. Adapun tujuan pengujian alat pencacah pakan ternak adalah:

- Mengetahui kerja dari mesin pencacah pakan ternak.

- Mengetahui hasil cacahan.

- Mengetahui kapasitas mesin pencacah pakan ternak.

- Mengetahui tingkat keberhasilan pencacahan

Hasil pengujian pakan ternak yang tercacah

Tabel 1 hasil pengujian mesin pencacah pakan ternak:

\begin{tabular}{|c|c|c|c|}
\hline Pengu1jian & $\begin{array}{c}\mathbf{W}_{\mathbf{1}} \\
\mathbf{( k g )}\end{array}$ & $\mathbf{W}_{\mathbf{2}} \mathbf{( \mathbf { k g } )}$ & $\begin{array}{c}\mathbf{T} \\
\text { (menit) }\end{array}$ \\
\hline 1 & $1,2 \mathrm{~kg}$ & $1 \mathrm{~kg}$ & 0,8 \\
\hline 2 & $2 \mathrm{~kg}$ & $1,8 \mathrm{~kg}$ & 1,5 \\
\hline 3 & $2,5 \mathrm{~kg}$ & 2.3 & 1,8 \\
\hline 4 & $1,5 \mathrm{~kg}$ & 1,3 & 1 \\
\hline Total & $\mathbf{7 , 2}$ & $\mathbf{6 , 5}$ & $\mathbf{4 , 9}$ \\
\hline
\end{tabular}

Keterangan:

$\mathrm{W} 1=$ Berat pakan ternak sebelum dimasukkan hopper ( $\mathrm{kg}$ )

$\mathrm{W} 2=$ Berat pakan ternak yang keluar $(\mathrm{kg})$

$\mathrm{t}=$ Waktu pencacahan ( menit)

Pakan ternak yang tercacah dan keluar $=\mathrm{w}_{-} 2 / \mathrm{w}_{-} 1.100 \%$

$=6,5 / 7,2.100 \%$

$=90,2 \%$ dari berat awal

Jadi dalam setiap sekali proses, pakan ternak yang tidak keluar 9,8 \% atau sebesar 0,7 kg. Kapasitas mesin (Q) $=7,2 \mathrm{~kg}$ dalam 4,9 menit ,jadi kapasitas yang diperoleh sebesar 88 $\mathrm{kg} /$ jam. Setelah dilakukan pengujian, besarnya kapasitas mesin tidak sesuai dengan yang diharapkan .Hal tersebut terjadi karena beberapa faktor, antara lain:

- Kurang tajamnya pisau pencacah.

- Dimensi pakan ternak yang berbeda beda mempengaruhi lama cacahan.
- Pakan ternak yang dicacah seharusnya pakan ternak kering.

- Perlu adanya pisau statis.

1.1. Analisa Hasil Pengujian

Berdasarkan data yang telah diperoleh dari pengujian alat, maka dapat disimpulkan sebagai berikut:

- Motor tidak sesuai dengan perhitungan yang didapat sehingga daya kurang

- Pulley penggerak dan digerakkan dapat berputar dengan baik dan tidak terjadi slip antara pulley dan sabuk -V

- Bantalan yang digunakan untuk menumpu poros berfungsi dengan sempurna dan halus.

- Rangka tidak mengalami getaran dan mampu menompang semua elmen mesin dengan baik.

- Hopper dapat berfungsi dengan baik karena dapat menampung pakan ternak secara efektif.

- Lubang out berfungsi dengan baik

Evaluasi Hasil Pelaksanaan

Survai awal yang dilakukan oleh Tim Pelaksana di Desa Alasrejo menemukan bahwa terdapat beberapa kendala yang dialami oleh masyarakat setempat khususnya para anggota kelompok ternak Joyo Panggung yaitu ketersediaan pakan yang berkualitas dan kontinyu. Hijauan pakan ternak yang diberikan masih sangat kurang baik dari aspek kualitas maupun kuantitas. Salah satu kendala utama adalah keterbatasan pengetahuan masyarakat peternak tentang cara mengawetkan hijauan pakan ternak pada saat produksinya berlimpah. Pemberian materi pelatihan dilakukan dengan cara metode ceramah, demonstrasi, dan eksperimen. Metode ceramah dilakukan dengan pemberian teori tentang pengawetan pakan dan cara pembuatan silase dan amoniasi jerami padi yang dilakukan di salah satu anggota kelompok ternak Joyo Panggung di Desa Alasrejo

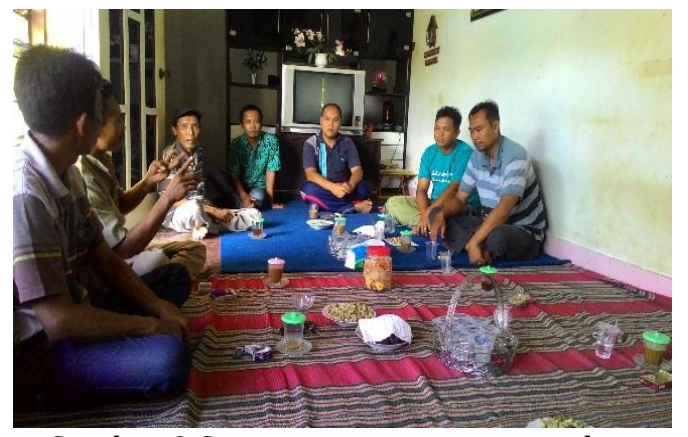

Gambar 3 Suasana penyampaian arahan 
Setelah ceramah dilanjutkan dengan demonstrasi dan eksperimen yang dilakukan di kandang kelompok ternak Joyo Panggung. Selama kegiatan pelatihan dari ceramah sampai pelaksanaan demonstrasi dan eksperimen para peserta terlihat cukup antusias mengikuti setiap tahapan kegiatan yang dibuktikan dengan adanya pertanyaan pertanyaan yang diajukan kepada pemateri.

\section{Evaluasi Hasil Silase}

Penilaian kualitas fisik terhadap silase yang dibuat dilakukan setelah 21 hari dari proses fermentasi yang dilakukan. Kriteria penilaian fisik silase dilakukan dengan berdasarkan hasil penelitian yang dilakukan oleh Syarifuddin (2006) pada aspek warna, bau, tekstur, dan jamur.

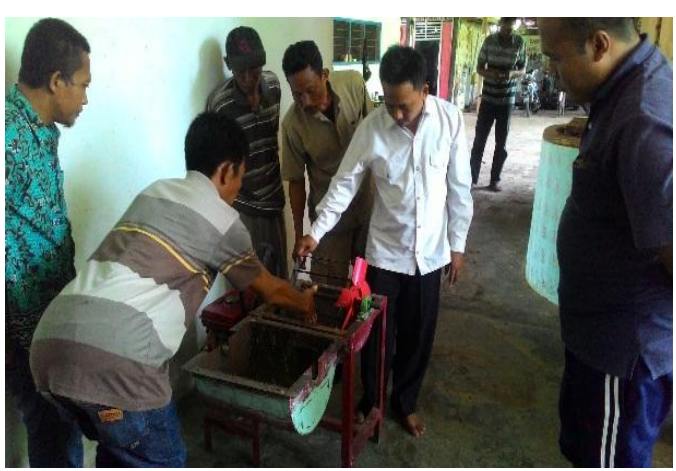

Gambar 4 Persiapan proses pencacahan

Berdasarkan hasil penilaian fisik berdasarkan warna, silase yang dihasilkan memiliki nilai skor 3 yang ditandai dengan warna hijau kekuningan. Perubahan warna silase dari warna asalnya menurut Reksohadiprodjo (1988) disebabkan oleh perubahan-perubahan yang terjadi dalam tanaman karena proses respirasi aerobik yang berlangsung selama persediaan oksigen masih ada, sampai gula tanaman habis. Gula akan teroksidasi menjadi CO2 dan air, dan terjadi panas hingga temperatur naik.

Bila temperatur tak dapat terkendali, silase akan berwarna coklat tua sampai hitam. Hal ini menyebabkan turunnya nilai makanan, karena banyak sumber karbohidrat yang hilang dan kecernaan protein turun, yaitu pada temperatur 55oC. Warna coklat pada silase disebabkan karena adanya pigment phatophytin suatu derivat chlorophil yang tak ada magnesiumnya.

Silase yang baik dengan temperatur yang naik tak terlalu tinggi kadar carotene tak berubah seperti bahan asalnya. Caroten hilang pada temperatur terlalu tinggi.
Tabel 2. Hasil Penilaian Kualitas Silase Yang Dihasilkan

\begin{tabular}{|l|l|l|l|}
\hline Indikator & Skor & \multicolumn{1}{|c|}{ Kriteria } & $\begin{array}{c}\text { Hasil } \\
\text { Penilaian }\end{array}$ \\
\hline Warna & $1-3$ & $\begin{array}{l}\text { 3. Hijau alami atau } \\
\text { hijau kekuningan } \\
\text { 2.Hijau gelap atau } \\
\text { kuning kecoklatan } \\
\text { 1.Coklat sampai } \\
\text { hitam }\end{array}$ & 3 \\
\hline Bau & $1-3$ & $\begin{array}{l}\text { 3. Asam } \\
\text { 2. Tidak asam atau } \\
\text { tidak busuk } \\
\text { 1. Busuk }\end{array}$ & 3 \\
\hline Tekstur & $1-3$ & $\begin{array}{l}\text { 3. Padat } \\
\text { 2. Agak lembek } \\
\text { 1. Lembek }\end{array}$ & 2 \\
\hline Jamur & $1-3$ & $\begin{array}{l}\text { 3. Tidak ada/ sedikit } \\
\text { 2. Cukup } \\
\text { 1. Banyak }\end{array}$ & 3 \\
\hline
\end{tabular}

Berdasarkan penilaian fisik berdasarkan bau, silase yang dihasilkan memiliki skor nilai 3 ditandai dengan bau asam yang timbul ada saat silo baru dibuka. Bau asam yang timbul disebabkan oleh bakteri asam laktat yang banyak timbul pada saat proses fermentasi terjadi. Sapienzah et al. (1993) menyatakan bahwa proses fermentasi dalam pembuatan silase terjadi karena adanya bakteri pembuat asam laktat yang berkembang baik dalam keadaan anaerob.

Tahap awal sel-sel tanaman atau hijuan yang akan dibuat silase masih hidup dan menggunakan oksigen (aerob) yang berada dalam silo, apabila oksigen telah habis terjadilah keadaan anaerob di dalam silo yang tidak memungkinkan lagi tumbuhnya jamur dan cendawan.

Pada kondisi tersebut maka bakteri pembuat asam laktat berkembang biak dengan cepat dan mengubah gula yang terkandung dalam hijauan menjadi asam-asam organik seperti asam asetat dan asam laktat. Dengan meningkatnya keasaman, kegiatan bakteri-bakteri pembusuk akan terhambat dan terhenti pada nilai $\mathrm{pH}$ sekitar 3,5 dimana bakteri pembuat asam laktat tidak perlu bereaksi lagi dan proses pembuatan silase pun selesai.

Berdasarkan penilaian tekstur, silase yang dibuat memiliki skor nilai 3 yaitu tekstur terasa padat ketika dipegang/digenggam. Secara umum silase yang baik mempunyai ciri - ciri yaitu tekstur masih jelas seperti alamnya (Siregar, 1996). Hasil penelitian Syarifuddin (2006) melaporkan bahwa tekstur silase pada berbagai umur pemotongan (20 hari hingga 80 
hari) menunjukkan skor tekstur antara 2 sampai dengan 3. Berdasarkan ada tidaknya jamur, silase yang dihasilkan selama pelatihan memilik skor nilai 3 yang artinya tidak ditemukan adanya jamur pada silase. Jamur yang tidak timbul menandakan suhu dalam silo dalam keadaan anaerob.

Hasil penelitian Ridwan et al. (2005) yang melaporkan bahwa suhu silase yang dihasilkan pada semua perlakuan berkisar antara 26-28oC. Silase masih dikatakan berhasil baik karena suhu panen yang dihasilkan beberapa derajat masih berada di bawah suhu lingkungan. Sebaliknya apabila melebihi suhu lingkungan sampai 5-10oC berarti silase tersebut diduga telah terkontaminasi mikoorganisme yang lain seperti kapang dan jamur.

\section{KESIMPULAN}

1. Berdasarkan hasil pengujian, prosentase pakan ternak yang keluar 90,2 \% sisanya 9,8 \% atau sebesar 7,2 kg tidak keluar, hal ini terjadi dalam setiap kali proses

2. Pelatihan pembuatan silase dan amoniasi jerami padi bagi masyarakat Desa Alasrejo Kecamatan Wogsorejo cukup berhasil berdasarkan sikap antusias peserta selama mengikuti kegiatan pelatihan

3. Silase yang dihasilkan cukup baik berdasarkan kriteria warna, bau, tekstur, dan kondisi jamur sehingga cukup layak untuk dikonsumsi ternak

4. Silase dari tanaman hijau (ruminansia) dapat dijadikan sumber pakan ternak pada saat musim kemarau di Desa Alasrejo, Kecamatan Wongsorejo

\section{UCAPAN TERIMA KASIH}

Tim mengucapkan terimakasih kepada institusi Politeknik Negeri Banyuwangi yang telah membantu di dalam pendanaan pengabdian ini. Terimakasih juga kepada Dinas Peternakan Kabupaten Banyuwangi, serta rekan - rekan yang telah banyak membantu hingga kegiatan ini dapat terlaksana dengan baik

\section{DAFTAR PUSTAKA}

[1] Bata, M. 2008. Pengaruh Molases Pada Amoniasi Jerami Padi Menggunakan Urea

[2] Terhadap Kecernaan Bahan Kering dan Bahan Organik In Vitro. Agripet : Vol (8)

[3] No. 2: 15-20

[4] Direktorat Jenderal Peternakan dan Kesehatan Hewan. 2011. Pedoman Umum

[5] Pengembangan Lumbung Pakan Ternak. ditjennak.pertanian.go.id/download.php?.

[6] Download Tanggal 27 Oktober 2016

[7] Hanafi, N.D. Perlakuan Silase Dan Amoniasi Daun Kelapa Sawit Sebagai Bahan Baku

[8] Pakan Domba. http://repository.usu.ac.id/bitstream/123456789/8 15/1/ternakNevy.pdf.

[9] Download 26 Oktober 2016

[10] Kamal, M. 1998. Bahan Pakan dan Ransum Ternak. Fakultas Peternakan, Universitas

[11] Gadjah Mada, Yogyakarta

[12] Kartasudjana R. 2001. Mengawetkan Hijauan Pakan Ternak. Departemen Pendidikan

[13] Nasional. Proyek Pengembangan Sistem dan Standar Pengelolaan SMK. Direktorat

[14] Pendidikan Menengah Kejuruan Jakarta

[15] Siregar, M. E. 1996. Pengawetan Pakan Ternak. Penebar Swadaya, Jakarta.

[16] Subekti, E. 2009. Ketahanan Pakan Ternak Indonesia. Mediagro Vol 5. No 2:63 - 71

[17] Syarifuddin.N.A. 2006. Karakteristik dan Persentase Keberhasilan Silase Rumput Gajah pada Berbagai Umur Pemotongan. Fakultas Pertanian Universtas Lambung

[18] Mangkurat, Banjarbaru.

[19] Hanafi, ND. 2008. Teknologi Pengawetan Pakan Ternak. Universitas Sumatera Utara.

[20] Kartasudjana, D. 2001. Mengawetkan Hijauan Pakan Ternak. Modul Keahlian Budidaya Ternak. Direktorat Pendidikan Menengah Kejuruan. http://files.ictpamekasan.nett/materikejuruan/pertanian/budi-dayaternakruminansia/mengawetkan-hijauan-pakan.pdf

[21] Nista, D. dkk. 2007. Teknologi Pengolahan Pakan: UMB, fermentasi jerami,amoniasi jerami, silage, hay. http://bptu_sembawa.net/VI/data/download/20090 816160949.pdf. 